\title{
Intercultural Primary Education in the Second Half of the Decade
}

\section{Róbert Osad'an - Elizabeth Reid - Mária Belešová ${ }^{*}$}

\begin{abstract}
Intercultural education advances the comprehension of different people and cultures. It emphasizes teaching that accepts and respects that diversity is normal in all areas of life. It attempts to sensitize the pupil to the concept that we all have developed in varied ways and that different does not mean "wrong". In the presented article, we deal with a term defined in the context of intercultural education. We think about the way of its implementation in primary education, while respecting all the attributes of cultural differentiation. Intercultural education examines forms of xenophobia, trying to diminish them, and advocates equal opportunities for all. Intercultural education works to modify individuals and institutions and so transform the society (What is intercultural education? Do we in the West have the materials to accomplish this in our classrooms?).
\end{abstract}

Key words: intercultural education, multicultural education, interculture, primary education.

\section{Introduction}

Cultural relativism reinforces the idea of equality between different cultures in terms of intrinsic value and discourages any attempt at proclaiming one culture as being superior or inferior to others. Values, norms, symbols of a culture must be evaluated within their context and functionality, and not by the criteria of a different culture (Cristea, 2012). Within the given context, the coexistence of several cultures in the same area gave rise to a set of related concepts: multicultural, intercultural, as well as multiculturalism, interculturality. The concepts of difference and diversity can create tension in themselves. As school populations become more diverse, instructors should understand the needs and cultural sensitivities of a broad range of learners and build means for working

* Róbert Osad'an, Comenius University in Bratislava, Faculty of Education, Bratislava, Slovakia; osadan@fedu.uniba.sk

Elizabeth Reid, Southern California Seminary, Department of Education, USA; reid.7343@gmail.com

Mária Belešová, Comenius University in Bratislava, Faculty of Education, Bratislava, Slovakia; belesova@fedu.uniba.sk 


\section{Acta Technologica Dubnicae \\ volume 6, 2016, issue 2}

with them effectively. Some of these groups include, but are not limited to, women; students with disabilities; students of color; gay, lesbian, bisexual, and transgender students; and increasingly, international students. The primary teacher also hopes to interact with the parents of these students and therefore must be sensitive to cultural differences. The establishment of the global vision and the improvement of intercultural communication skills demand students to acquire basic intercultural knowledge, global awareness, attitudes to respect multiculturalism, and common values in different cultures (Huang, 2015). How can we reach a new social perception of difference? First of all, by means of transcultural education promoting a positive approach of the difference. This entails the notions of interaction, exchanges, reciprocity, real solidarity, equality of chances, etc. Second of all, the acceptance of these differences and the education in the spirit of interculturality (Bortun, 2013).

We use the term intercultural education to include multicultural education, antiracist education, human rights education, active citizenship, inclusive education, conflict-resolution, bi-lingual and multilingualism, gender and LGBT issues and anything that promotes prejudice and detracts from tolerance and acceptance of others and their culture, customs and traditions (Garcia). Hopefully, we have had some practice incorporating methods and materials into the curriculum with these groups, as schools in the West now are receiving unprecedented numbers of students from Africa and the Middle East.

\section{Aspects of intercultural education}

Intercultural education has been proven to bring positive results in terms of lowering racial prejudice, developing learner and social identity, celebrating diversity, promoting human rights and citizenship (Róg, 2015). Human rights are universal but the right to maintain cultural differences sometimes challenges human rights (UNESCO Guidelines on Intercultural Education, 2010). Balancing cultural diversity and human rights is a delicate act. All pupils benefit from learning about diverse cultures and meeting people with different perspectives, while those from underrepresented groups are encouraged when their contributions are recognized (International Association for Intercultural Education). There are three aspects of intercultural education: teaching a classroom of diverse students, intercultural teaching methods and multicultural content or teaching materials. The diverse classrooms have already come to the West and the classroom population portends to become even more diverse in the coming years. The school is the most visible educational aspect of Western societies, and its effectiveness is central to the development of democratic society. Its goal is to develop the potential of students through knowledge and the building of competences, values and attitudes that prepare them for productive life in society. 


\section{Acta Technologica Dubnicae \\ volume 6, 2016, issue 2}

The major challenge when discussing the issue of education and multiculturalism is dealing with some of the inherent tensions that arise in reconciling competing world views with each other. Such tensions reflect the diversity of values, which co-exist in a multicultural world. Often, they cannot be resolved in a single "either/or" solution. However, the dynamic interchange between competing aspects is what lends richness to the debate on education and multiculturalism. On one side the definitions of intercultural education appear to be often imprecise, incomplete, and even simplistic. It is, in general, considered a method to teach in multi-ethnic classrooms avoiding behaviours of intolerance or even racism. In addition, although some of the "political" documents show awareness of some kind of relation of foreign language learning to intercultural education, the way how one affects the other and vice-versa is not completely explored (Ferrari, 2015).

Our world is experiencing rapid change and cultural, political, economic and social upheaval challenge traditional ways of life. Education plays a major role in promoting social cohesion and peaceful coexistence. Programmes that encourage dialogue among students of different cultures, beliefs and religions can make an important and meaningful contribution to sustainable and tolerant societies. Education not only reflects society but also molds its development (Intercultural Education in the primary school, 2005). Teachers have an important role to play in the development of a tolerant, peaceful intercultural society. Education is no miracle worker, but it can challenge racism and promote intercultural awareness. Education develops the child's intercultural skills, attitude of tolerance, and knowledge. An intercultural education is valuable to all children in equipping them to participate in an increasingly diverse society. Intercultural Education can provide a quality education for all. Yet Intercultural education must promote diversity in universality - a difficult challenge. The aims of Intercultural Education are summarized nicely in 'the four pillars of education' identified by the International Commission on Education for the Twenty-First Century (1996): Learn to know, Learn to do, Learn to live together, Learn to be.

\section{Background of intercultural education}

The Universal Declaration of Human Rights (United Nations, 1948) stated, "Education shall be directed to the full development of human personality and to the strengthening of respect for human rights and fundamental freedoms. It shall promote understanding, tolerance and friendship among all nations, racial and religious groups, and shall further the activities of the United Nations for the maintenance of peace." The statement challenges the traditional social concepts of "Us" and "Them" or "Insiders versus Outsiders". This statement might be called the beginning of awareness of a need for intercultural education but did 


\section{Acta Technologica Dubnicae \\ volume 6, 2016, issue 2}

not necessarily trigger action until special interest groups demonstrated their demands. The governability of all pluralistic, democratic societies increasingly depends on the ability of the governments to provide equity in public and social life, and to educate citizens to be open to intercultural dialogue and be tolerant of each other's ways of being, doing and thinking (The National Association for Multicultural Education).

The decade of the 1960s was a period of social activism and change when people of the West were forced to reexamine their cultural heritage and multicultural education began to emerge to address the educational needs of a society that continues to struggle with the realization that it is not monocultural, but is an amalgamation of many cultures. In the 1970s, ethnic minorities and women confronted racism and sexism in society as seen in a monocultural education. Women had been struggling for rights for decades and had gained the right to vote and to drive automobiles. The World Wars granted women the right to work in the West out of necessity and many of them never went back into the home. Ethnic studies and women's studies developed in the 70s to add their traditionally silenced voices to the education and therefore to the development of the culture. These sectors were followed by people with disabilities, various religions and more minority cultures in the late twentieth century. Many national governments made a commitment at the World Conference against Racism in Durban in 2001 to develop and implement a National Action Plan Against Racism. Much Intercultural Education in today's classrooms stems from this conference, although much had been done previously. Both educators and students must participate in integration, as it is a two-way dynamic, not the sole concern of one or the other. Intercultural education is not meant as a radical change and is not resource intensive. It needs respect for difference, and an evolving change of attitude. C. E. Sleeter (1996, as cited by Hanley, 2012) in his paper, "Multicultural education as social activism," delineated five approaches to multicultural education:

- Advocates of the Teaching the Culturally Different approach attempt to raise the academic achievement of students of color through culturally relevant instruction.

- In the Human Relations approach students are taught about commonalities of all people through understanding their social and cultural differences but not their differences in institutional and economic power.

- The Single Group Studies approach is about the histories and contemporary issues of oppression of people of color, women, low socioeconomic groups, and gays and lesbians.

- The Multicultural Education approach promotes the transformation of the educational process to reflect the ideals of democracy in a pluralistic 


\section{Acta Technologica Dubnicae \\ volume 6, 2016, issue 2}

society. Students are taught content using instructional methods that value cultural knowledge and differences.

- Educators who use the Social Reconstructionist approach to multicultural education go a step further to teach students about oppression and discrimination. Students learn about their roles as social change agents so that they may participate in the generation of a more equitable society.

These categories overlap, and educators may use more than one approach simultaneously. The Multicultural Education and Human Relations approaches seem most appropriate to the lower primary grades, while the other three approaches can be incorporated in the upper primary grades. The inclusion of an occasional holiday or hero in a curriculum which leaves the European American story as the main narrative the West cannot create the understanding needed for a multicultural society, nor can it provide the kind of education needed to educate a multicultural populace to become active citizens of a democracy (What is intercultural education?).

\section{Intercultural education today and into the future}

UNESCO (Guidelines) has developed three principles for intercultural education which are good to review:

Principle I. Intercultural Education respects the cultural identity of the learner through the provision of culturally appropriate and responsive quality education for all.

Principle II. Intercultural Education provides every learner with the cultural knowledge, attitudes and skills necessary to achieve active and full participation in society.

Principle III. Intercultural Education provides all learners with cultural knowledge, attitudes and skills that enable them to contribute to respect, understanding and solidarity among individuals, ethnic, social, cultural and religious groups and nations.

The European integration process raised, in turn, a series of problems. Membership in the European cultural space and the construction of what we call European cultural identity requires an inter-sectorial approach to harmonize economic, commercial, social goals with the cultural ones. The Pan-European space, thus shaped, the diversity of cultural practices and traditions of European countries must be perceived as wealth and not as a source of division and conflicts (Pasca, 2012). In the twenty-first century with massive migration going on, intercultural education must continue to change and not only include 


\section{Acta Technologica Dubnicae \\ volume 6, 2016, issue 2}

traditional minorities but the minority cultures of refugees and migrants from the Middle East and Africa. These changes must include customs, values, religions and differing gender roles of the cultures of these recent arrivals to Europe and the West without diminishing the attention already devoted to minority races, women, LGBT, disabilities and other minority groups. The recent migration of those fleeing the Middle East and Africa is changing the profile of classrooms in the West and appears to be set to continue adding sizable numbers of migrants with backgrounds very different than those of the children who currently fill the classrooms of the Western countries. Since the Enlightenment in the West, there is a tendency to downplay religion in public life. Nevertheless, there is a growing visibility of religious or spiritual belief and practice now in political thought and social activity. Conflict which uses religion as a motive is increasing and the search for religious meaning is taking on new forms (UNESCO). Students are not only multicultural now, but also multi-faith. It would seem appropriate for these newer students to include materials previously excluded because they were deemed common knowledge, like Christianity and Judaism in the comparative religions. It should not be taken for granted that the perceived common knowledge of students is accurate. UNESCO states in its guidelines on intercultural education, "It is fundamentally important that democratic societies address inter-religious issues through education."

Most of the migrants and refugees entering the West are coming from Muslim countries. As with all cultures, the customs and values which are held and practiced in Muslim countries are not better or worse than those held in the West, they are only different. Moreover, many migrant children have not attended school for months or even years, as it was unsafe or their school was destroyed. This challenge will be added to that of learning (Byram, 2015) the local language if the child does not already speak it. If a child has a disability, it may be necessary to convince the parents that there is still schooling available for such a child.

Gender roles in particular are more traditional in Middle Eastern cultures than in the West. Education may be valued for boys more than for girls. It is expected that the girls in the family will eventually marry and go to be part of their husband's family, serving as his wife and the mother of his children in the home. After a long and continuing social struggle for women's rights and equal pay for equal work, many women in the West may see this as "giving up the struggle" before the fight is won. Teachers may find that they must work on their own attitudes, as being wife and mother is an acceptable career choice. While the primary teacher is not usually involved in career guidance, this value may still manifest in inconvenient ways. Girls may be kept home from school to care for younger children and/or do the cooking when their mother is not available for whatever reason, whether giving birth to a sibling or taking another child to the 


\section{Acta Technologica Dubnicae \\ volume 6, 2016, issue 2}

doctor. It may be difficult to explain to the parents that learning is important for girls, even on the elementary level. The girl still needs to be able to read and do basic maths in order to shop and follow a recipe. It may be just as difficult for Western career women to realize that many women find fulfillment in the roles of mother and wife and that this is a valid life choice but one that should be made later in the girl's life.

Religion, in the form of comparative religion, has begun to be taught in many schools which will ease the teacher's role. While many people in the West do not profess any particular belief, it is important to respect those who do hold to a specific religion, be they students, parents or other adults. In this vein, no religion or its practicants should be belittled. Particularly in regard to religion, the issue of tolerance is likely to come up. While some religions teach that they should be shared with others by conversion, students should be instructed that in a democracy each person is allowed to choose his or her religion or none. Proselytizing should be discouraged by anyone on the school grounds; if they want to share their religion it should be done outside of school hours and off the campus.

Touching both gender roles and religion, Muslims worship on Fridays. Observant men who are going to the mosque may not want to touch a woman or girl, or even take something from them directly, in order to maintain his purity for his visit to the mosque. Different Muslim countries and cultures vary on whether women also attend mosque; if they do, they sit in a separate area. This custom may affect parent/teacher conferences and assemblies when parents are invited to attend.

Various other customs may affect the primary classroom. Most Westerners have become accustomed to women and girls wearing head scarves but there are many other customs. Many Middle Eastern cultures find it offensive to show the sole of the foot to another person, whether shod or not. This can cause unintended offence when Westerners lift their foot to show their new shoes to another person. Teachers might wonder why some students sitting cross-legged on the floor will twist their feet under them in uncomfortable-looking ways. This may be the motive. There are too many various customs to enumerate them here. A sense of exploration, openness to learn, slowness to take offence and willingness to forgive will go a long way toward smoothing ruffled feathers when there are misunderstandings. More teacher training in intercultural issues would help sensitize teachers to many potential problems and help them deal with them diplomatically and efficiently. 


\section{Acta Technologica Dubnicae \\ volume 6, 2016, issue 2}

\section{Conclusion}

Intercultural education enacts social change by way of education toward a more tolerant, accepting society. It requires imagination, critical thinking, and commitment to a different tomorrow, inclusive of all of our histories and peoples. It is part of the continuous human journey toward justice and pushes us toward fulfilling the promises of democracy. The goals of intercultural education for the second half of this decade are not different than before. They remain:

Creating a safe, accepting and successful learning environment for all;

- Increasing awareness of global issues;

- Strengthening cultural consciousness;

- Strengthening intercultural awareness;

- Teaching students that there are multiple historical perspectives;

- Encouraging critical thinking;

- Preventing prejudice and discrimination.

The audience of students and their parents has changed and will continue to change to incorporate many newcomers from Middle Eastern and African countries who hold the values, religions and customs of those cultures from which they came. While not everything about their customs will be new to teachers in the West, there will still be many new things we can learn from them and about them.

While there are many materials available for incorporation into the curriculum, there is room for continued review and revision of teaching materials. The teacher may find lots of materials available online, but finding them can be time consuming. Materials like The Big Myth, make available creation myths from many cultures in an interactive website (http://www.bigmyth.com/) available in English, German and Dutch. These can be adapted to the primary classroom, reminding students that if they find differences in the story, it is because the myth associated with their culture has not been read yet. But finding these materials can add hours to the teacher's work. Perhaps more helpful would be intercultural training for teachers to make them aware of potential problems and help them work with students from varied backgrounds.

Within today's changing societies teachers must meet the needs of a culturally diverse student body. Beyond cultural awareness, or what may be generally termed "tolerance", teachers more and more need to identify cultural implications and adapt pedagogical approaches to meet students' cultural and academic needs (Mc Keown \& Kurt, 2012). 


\section{Acta Technologica Dubnicae \\ volume 6, 2016, issue 2}

The need for thoroughly integrated textbooks which incorporate multiple historical views, social customs and religious traditions is clear. New illustrations with multiple races and abilities represented are not enough. Adding a holiday celebration or occasional hero of another culture is not enough. A thorough review and revision of texts and curricula are needed to meet the needs of today's multicultural children who will grow up to be tomorrow's leaders and citizens. It is not the job of teachers to reconcile conflicting view in a multicultural world, only to present them without prejudice. It helps if we prepare our students by reminding them occasionally that we are all different, not better or worse, just different. We can learn from each other and with patience and forgiveness; we can learn together and build bonds that will form strong friendships. The varied students we teach can grow up to be active participants in a free, democratic society.

\section{References}

Bortun, D. (2013). Intercultural education and transcultural education. Euromentor Journal, 4(2), 15-22.

Byram, M. (2015). Researching Intercultural Learning: Investigations in Language and Education. Elt Journal, 69(3), 331-334.

Cristea, N. (2012). The operationalisation of intercultural education contents in initialand and continuous teacher education programmes in Romania. The Journal of Linguistic and Intercultural Education, 5, 59-66.

Ferrari, G. (2015). Steps towards intercultural education and the role of language learning. The Journal of Linguistic and Intercultural Education, 8, 87-106.

Garcua, E. K. Multicultural Education in Your Classroom. Retrieved from http://www.teachhub.com/multicultural-education-your-classroom

Hanley, M. S. (2012). School of Education at Johns Hopkins University-The Scope of Multicultural Education. Retrieved from http://education.jhu.edu /PD/newhorizons/strategies/topics/multicultural-education/the-scope-ofmulticultural-education/

Huang, L. (2015). Improving intercultural education at chinese institutions from german experience. Journal of International Students, 5(2), 201-203.

IAIE: International Association for Intercultural Education. Retrieved from http://www.iaie.org/1_about.html

International Commission on Education for the twenty-first Century. (1996). UNESCO Publishing. Retrieved from http://portal.unesco.org/education/en/ ev.php-URL_ID=13001\&URL_DO=DO_TOPIC\&URL_SECTION=201. html

Intercultural Education in the primary school. (2005). Dublin: NCCA. Retrieved from: http://www.ncca.ie/en/Curriculum_and_Assessment/Inclusion/ Intercultural_Education/ 


\section{Acta Technologica Dubnicae \\ volume 6, 2016, issue 2}

Mc Keown, J., \& Kurt, I. (2012). 'BEHOLD ECCO': using the "Educational cultural cenvergence" model in intercultural education. Review of the Air Force Academy, 3, 45-54.

Pasca, E. M. (2012). Teacherswith artistic specialization between cultural and intercultural education. Review of Artistic Education, 3/4, 135-142.

Róg, T. (2015). Intercultural education at pre-school level in the context of polish kindergarten curriculum changes. The Journal of Linguistic and Intercultural Education, 8, 179-201.

Sleeter, C. S. (1996). Multicultural education as social activism. Journal of teacher education, 52(2), 94-106.

The National Association for Multicultural Education. Retrieved from http://www.nameorg.org/index.php

The Universal Declaration of Human Rights/United Nations. (1948). Retrieved form http://www.un.org/en/universal-declaration-human-rights/

UNESCO Guidelines on Intercultural Education. (2010). Retrieved from http://unesdoc.unesco.org/images/0014/001478/147878e.pdf

What is intercultural education? Retrieved from http://ien.inclusion.msu.edu/ node/ 130 